\title{
The genus Euastrum Ehrenberg ex Ralfs (Desmidiaceae) in a subtropical stream adjacent to the Parque Nacional do Iguaçu, Paraná State, Brazil
}

\author{
Camila Akemy Nabeshima Aquino ${ }^{1,2,3}$, Norma Catarina Bueno ${ }^{1,2}$, Liliane Caroline Servat ${ }^{1,2}$ and \\ Jascieli Carla Bortolini²
}

Received: 7.07.2016; accepted: 8.11.2016

\begin{abstract}
The genus Euastrum Ehrenberg ex Ralfs (Desmidiaceae) in a subtropical stream adjacent to the Parque Nacional do Iguaçu, Paraná State, Brazil). This study aimed to document the species of Euastrum (Desmidiaceae) in a subtropical stream adjacent to an important environmental protection area, the Parque Nacional do Iguaçu, in the extreme west of Paraná State, Brazil. For this purpose, monthly samplings of periphytic material associated to Eleocharis minima Kunth were performed in the period between August 2012 and July 2013. This taxonomic inventory allowed the identification of 12 taxa at specific and infraespecific level. Eight new occurrences were recorded for Paraná State: Euastrum attenuatum var. splendens, E. bidentatum var. bidentatum, E. cornubiense var. cornubiense, E. croasdaleae var. croasdaleae, E. denticulatum var. quadrifarium, E. didelta var. quadriceps, E. elegans var. elegans and E. evolutum var. incudiforme.
\end{abstract}

Keywords: biodiversity, desmids, Freshwater, taxonomy, Zygnematophyceae

RESUMO - (O gênero Euastrum Ehrenberg ex Ralfs (Desmidiaceae) em um riacho subtropical, área adjacente ao Parque Nacional do Iguaçu, PR, Brasil). Este estudo objetivou documentar as espécies do gênero Euastrum (Desmidiaceae) em um riacho subtropical adjacente a uma importante área de proteção ambiental, o Parque Nacional do Iguaçu, no extremo oeste do Estado do Paraná, Brasil. Para isso, foram realizadas amostragens mensais de material perifítico associado a Eleocharis minima Kunth no período de agosto de 2012 a julho de 2013. Este inventário taxonômico possibilitou a identificação de 12 táxons em nível específico e infraespecífico. Foram registradas oito novas ocorrências para o Estado do Paraná: Euastrum attenuatum var. splendens, E. bidentatum var. bidentatum, E. cornubiense var. cornubiense, E. croasdaleae var. croasdaleae, E. denticulatum var. quadrifarium, E. didelta var. quadriceps, E. elegans var. elegans and E. evolutum var. incudiforme.

Palavras-chave: Água doce, biodiversidade, desmídias, taxonomia, Zygnematophyceae

\section{Introduction}

Euastrum Ehrenberg ex Ralfs (1848) comprises a cosmopolitan distribution genus, belonging to the Desmidiaceae (Zygnematophyceae) family. It has isolated cells, about 2 times longer than wide, or about as long as wide, divided in two semicells. The semicells can be divided into 3 lobes, being 2 basal lobes and one polar lobe (or apical lobe). Many species can present lateral lobes among the basal lobes and the polar lobe.

An important characteristic of the genus is the presence of a median apical incision in most of its representatives, which can be deep or shallow, narrow or open, U-shaped or V-shaped. In lateral view the cells are usually oval, rarely elliptic and subretangular, with narrow or acute spines and truncate poles. In apical view the cells are elliptic, oval, or quadratic, mainly with rounded poles, and showing lateral protuberances. The cell wall can be smooth, punctuated or scrobiculated. It occurs one chloroplastid in each semicell, with usually 1 pyrenoid, in some cases, two or several pyrenoids (Prescott et al. 1977, Bicudo \& Menezes 2006, Franceschini et al. 2010).

For the Paraná State, 11 studies have contributed to desmids knowledge, approaching the Euastrum

1. Universidade Estadual do Oeste do Paraná, Programa de Pós-Graduação em Conservação e Manejo de Recursos Naturais, Rua Universitária 2069, Jardim Universitário, 85819-110 Cascavel, PR, Brasil

2. Universidade Estadual do Oeste do Paraná, Laboratório de Ficologia, Rua Universitária 2069, Jardim Universitário, 85819-110 Cascavel, PR, Brasil

3. Corresponding author: camilaakemy@yahoo.com.br 
genus: Picelli-Vicentim (2001), Biolo et al. (2008), Felisberto \& Rodrigues (2005a, b, 2008, 2010a), Bortolini et al. (2008, 2010), Menezes et al. (2011, 2013) and Aquino et al. (2014). There are no studies encompassing exclusively the Euastrum genus.

This study, although in a qualitative character, highlights the importance of the Brazilian phycological flora knowledge. This also emphasizes the need of knowing the taxa biogeography, once known species number is probably much lower than the real number of existent species, since many habitats and regions have not been sampled yet. Besides, the phycological flora knowledge is extremely necessary as a comparative base for ecological studies in continental aquatic environments, as well to propose biodiversity protection and conservation measures. In face of that, this study aimed to document taxonomically the occurrence of the taxa belonging to the Euastrum genus in a subtropical stream, adjacent to Parque Nacional do Iguaçu, an important environmental protection area located in the further western of Paraná State, Brazil.

\section{Material and methods}

The study was conducted at Tenente João Gualberto stream, an important tributary of the lower Iguaçu River hydrographic basin, located in São Miguel do Iguaçu municipality $\left(25^{\circ} 20^{\prime} \mathrm{S}\right.$ and $\left.54^{\circ} 14^{\prime} \mathrm{W}\right)$, further western of Paraná State, Brazil. This stream is situated in an area adjacent to the Parque Nacional do Iguaçu, the first Brazilian Conservation Unit to be instituted as World Natural Heritage Site by UNESCO. This region has a mesothermal-humid subtropical climate, with well-defined summer and winter periods, and rainfalls regularly well distributed all over the year (Alvares et al. 2014). The sampling station (figure 1) is a small watercourse, approximately $3.4 \mathrm{~m}$ large between margins, about $20 \mathrm{~cm}$ deep. The area presents approximately $2 \mathrm{~m}$ of riparian vegetation in its surroundings.

The biological material samplings were performed in the period between August 2012 and July 2013, totalizing 12 months of samplings. The periphytic material was collected from the aquatic macrophyte Eleocharis minima Kunth, being removed with the help of a brush and distilled water jets. Samples were preserved in Transeau solution, in the proportion of $1: 1$, according to Bicudo \& Menezes (2006). The biological material is deposited in the State University of West Paraná (UNIOESTE) Herbarium, Cascavel campus (UNOP-Algae).

For the qualitative analysis an average of 15 slides per sample were prepared. The microalgae morphometric and photographic analysis was performed in a trinocular microscopic with infinite correction optical, Olympus model CX31, with camera attached. The systematic and taxonomic framework for the identified taxa was performed based on the classic literature of Prescott et al. (1977), as well as in specialized scientific papers.

The measures (in $\mu \mathrm{m}$ ) are represented by the symbols: L - length, W- width and I - isthmus, and the morphometric data were recorded for all the taxa. The taxa geographic distribution was obtained in Guiry $\&$ Guiry (2016). It was also verified the occurrence of taxa for Paraná State. Comments were elaborated when deemed necessary.

\section{Results and Discussion}

The taxonomic study of the genus Euastrum at the Tenente João Gualberto stream adjacent to the Parque Nacional do Iguaçu, western of the State of Paraná, Brazil, resulted in the identification of 12 taxa, eight being new occurrences for the State of Paraná: E. attenuatum var. splendens (Fritsch \& Rich) Gromblad \& Scott, E. bidentatum Nägeli var. bidentatum (Schmidle) Krieger, E. cornubiense West \& G.S. West var. cornubiense, E. croasdaleae Grönblad var. croasdaleae, E. denticulatum (Kirchn.) F. Gay var. quadrifarium Willi Krieg. in Kolkwitz, E. didelta (Turpin) Ralfs var. quadriceps (Nordst.) Willi Krieg. in Kolkwitz, E. elegans (Bréb.) Kütz. ex Ralfs var. elegans, E. evolutum var. incudiforme (Börges) West \&West. All the inventoried taxa are identified in the artificial key below and then described.

Euastrum Ehrenberg ex Ralfs

Artificial key to the identification of Euastrum Ehrenberg ex Ralfs recorded at the Tenente João Gualberto stream, Paraná, Brazil. Taxa with asterisk are new records:

1. Semicells without apical incision E. attenuatum var. splendens*

1. Semicells with apical incision

2. Semicells with shallow median apical incision

3. Semicells trapeziform E. insulare var. insulare

3. Semicells pyramidal 
4. Semicells pyramidal with one undulation between the apical and basal lobes

E. croasdaleae var. croasdaleae*

4. Semicells pyramidal with two undulations between the apical and basal lobes

E. cornubiense var. cornubiense*

2. Semicells with deep median apical incision

5. Semicells with closed apical incision

6. Semicells with apex slightly inflated and surrounded by large granules

E. didelta var. quadriceps*

6. Semicells with apex truncate and without inflations

E. ansatum var. ansatum

5. Semicells with open apical incision

7. Face of semicell with the presence of granules

8. Cells subretangular with rounded basal lobes with one undulation ...... E. denticulatum var. denticulatum

8. Cells rectangular-pyramidal with basal lobes with two undulations ...... E. denticulatum var. quadrifarium*

7. Face of semicell with the presence of spines

9. Cells $<30 \mu \mathrm{m}$

10. Apical margin angular and with a broad $\mathrm{V}$-shaped invagination ....... E. bidentatum var. bidentatum*

10. Apical margin truncate and with a broad U-shaped invagination ................. E. elegans var. elegans*

9. Cells $>30 \mu \mathrm{m}$

11. Apical margin with a prominent upwardly directed spine

E. evolutum var. evolutum

11. Apical margin with a prominent spine extended to the angles E. evolutum var. incudiforme*

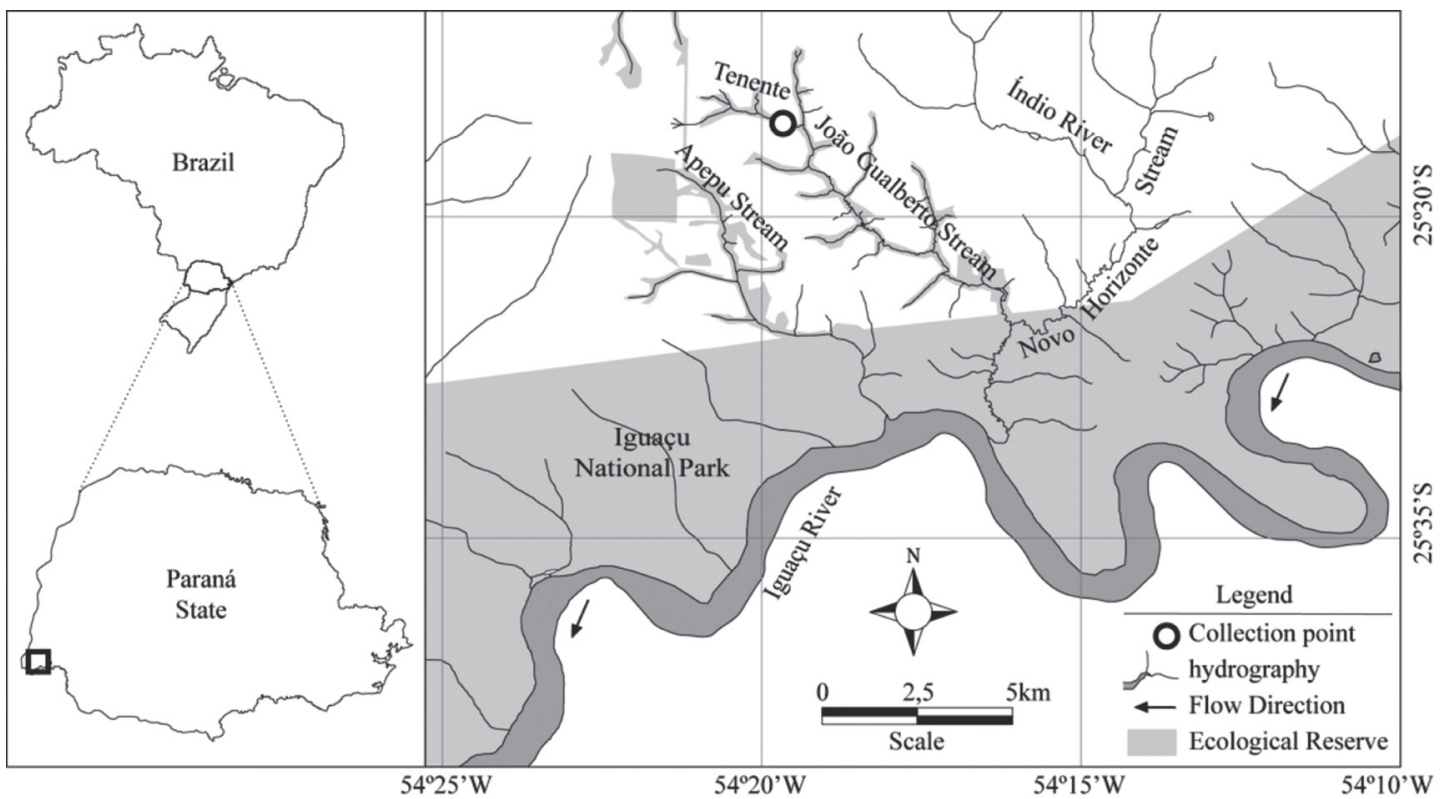

Figure 1. Location of the sampling station in the Tenente João Gualberto Stream, Parque Nacional do Iguaçu, Paraná State, Brazil.

Euastrum ansatum Ehrenb. ex Ralfs var. ansatum,

Brit. Desmid.: 85, pl. 14, fig. 2a-f. 1848.

Figures 2-3

Cells longer than wide. L: 61.6-94.7 $\mu \mathrm{m} ; \mathrm{W}: 25.0-46.6$ $\mu \mathrm{m}$; I: 9-13.3 $\mu \mathrm{m}$. Semicell pyramidal-truncate, 3-lobed, deep median constriction, median sinus closed, truncate apical margin, rounded angles, lateral margins concave at the basal lobes and parallel at the apical lobe, rounded basal angles. Apical and lateral view not observed. Cell wall punctate. Chloroplastid with one pyrenoid per semicell.
Material examined: BRAZIL. PARANÁ: São Miguel do Iguaçu, Tenente João Gualberto Stream, 29-X-2012, L.C. Servat (UNOP-Algae3962).

Occurence in the Paraná State: Bortolini et al. (2008), Menezes et al. (2013), Aquino et al. (2014).

Euastrum attenuatum var. splendens (Fritsch \& Rich) Gronblad \& Scott, in Gronblad, Prowse \& Scott, Acta Bot. Fennica 58: 12 figs. 33-34. 1958.

Figures 4-6 


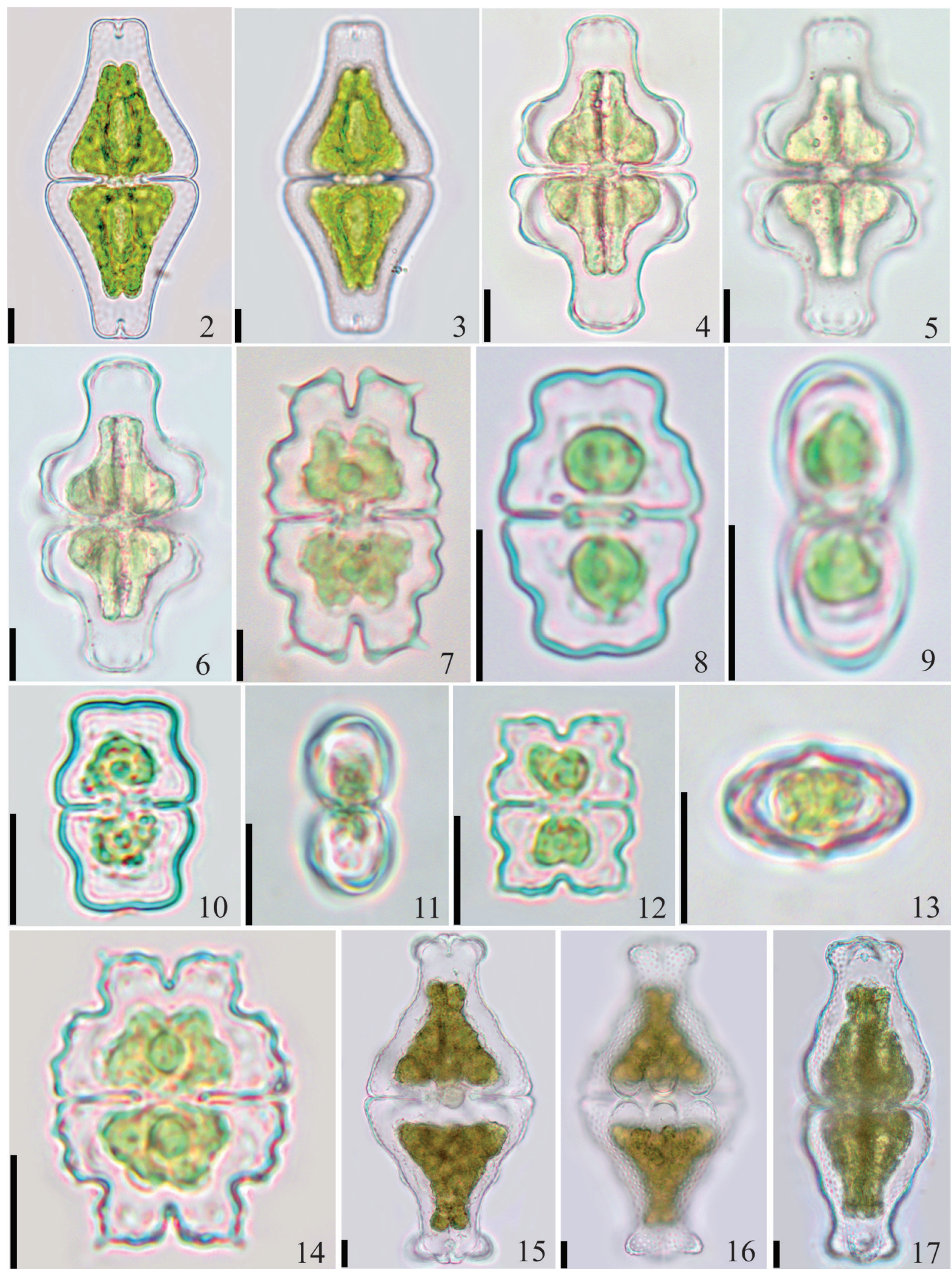

Figure 2-17. Euastrum Ehrenberg ex Ralfs in lotic environment adjacent to the Iguaçu National Park, Paraná, Brazil. 2-3. Euastrum ansatum var. ansatum. 3. Detail of the cell wall. 4-6. E. attenuatum var. splendens. 5-6. Detail of the wall ornamentation. 7. E.bidentatum var. bidentatum. 8-9. E. cornubiense var. cornubiense. 9. Lateral view. 10-11. E. croasdaleae. var. croasdaleae. 11. Lateral view. 12-13. E. denticulatum var. denticulatum. 13. Apical view. 14. E. denticulatum var. quadrifarium. 15-17. E. didelta var. quadriceps. 16. Detail of the wall punctuations. 17. Lateral view. Scale $=10 \mu \mathrm{m}$. 
Cells longer than wide. L: 50-52.5 $\mu \mathrm{m}$; W: 29.0-33 $\mu \mathrm{m}$; I: 6-9.9 $\mu \mathrm{m}$. Deep median constriction, sinus open, semicell subquadrate, without median incision, with a protrusion surrounded by large granules, concave margins forming a polar lobe with subparallel margins, the apex slightly inflated. Face of the semicell with a median inflation surrounded by large granules and with a large inflation on both sides of the basal lobes. Lateral view elliptic. Apical view not observed. Cell wall smooth. Chloroplastid with two pyrenoids per semicell.

Material examined: BRAZIL. PARANÁ: São Miguel do Iguaçu, Tenente João Gualberto Stream, 29-X-2012, L.C. Servat (UNOP-Algae3962).

Occurrence in the Paraná State: First record of the taxon.

According to Prescott et al. (1977) the variety splendens (Fritsch \& Rich) Gromblad \& Scott differs from the typical variety by having the basal lobes broadly extended and rounded, from a broadly open sinus. The individuals found showed smaller size when compared to the ones cited Prescott et al. (1977), which the length would be 61-66 $\mu \mathrm{m}$; width $39 \mu \mathrm{m}$ and isthmus of 11-12 $\mu \mathrm{m}$.

Euastrum bidentatum Nägeli, 1849, Gatt. Einz. Algen, p.122. pl. 7-D: figs 1a-f var. bidentatum Figure 7

Cells longer than wide. L: 20.5-26.2 $\mu \mathrm{m}$; W: 13.2-17.3 $\mu \mathrm{m}$; I: 3.3-4 $\mu \mathrm{m}$. Deep median constriction, sinus almost closed, semi-elliptical semicell with rounded poles and with undulate margins, apical margin angular and with a wide incision V-shaped, ornamented with spiniferous processes at the terminal angles. Face of the semicell with a median protrusion ornamented with several granules. Apical and lateral view not observed. Cell wall smooth. Chloroplastid with one pyrenoid per semicell.

Material examined: BRAZIL. PARANÁ: São Miguel do Iguaçu, Tenente João Gualberto Stream, 25-IX-2012, L.C. Servat (UNOP-Algae3943); Tenente João Gualberto Stream, 29-X-2012, L.C. Servat (UNOPAlgae3962); Tenente João Gualberto Stream, 6-II-2013, L.C. Servat (UNOP-Algae4057); Tenente João Gualberto Stream, 11-III-2013, L.C. Servat (UNOP-Algae4081); Tenente João Gualberto Stream, 6-VI-2013, L.C. Servat (UNOP-Algae4116); Tenente João Gualberto Stream, 16-VII-2013, L.C. Servat (UNOP-Algae4126).
Occurrence in the Paraná State: First record of the taxon.

The individuals found presented inferior sized than the ones cited by Prescott et al. (1977), being close to cited by Silva e Felisberto (2015) which the length would be 31-34 $\mu \mathrm{m}$; width 19-21 $\mu \mathrm{m}$ and isthmus of 4-5 $\mu \mathrm{m}$, although all the other characteristics are in accordance with the description.

Euastrum cornubiense West \& G.S. West var. cornubiense Monogr. 2: 70, pl. 40, fig. 8. 1905.

Figures 8-9

Cells longer than wide. L: 15-21.1 $\mu \mathrm{m}$; W: 9.9-15.1 $\mu \mathrm{m}$; I: 2.0-4.0 $\mu \mathrm{m}$. Deep median constriction, linear sinus closed, semicells pyramidal with lateral margins rounded and two undulations, apical margin rounded with a slight incision. Face of the semicell with a slight protuberance and absence of granules. Lateral view oval. Apical view not observed. Cell wall smooth. Chloroplastid with one pyrenoid per semicell.

Material examined: BRAZIL. PARANÁ: São Miguel do Iguaçu, Tenente João Gualberto Stream, 30-VIII-2012, L.C. Servat (UNOP-Algae3930); Tenente João Gualberto Stream, 25-IX-2012, L.C. Servat (UNOPAlgae3943); Tenente João Gualberto Stream, 29-X-2012, L.C. Servat (UNOP-Algae3962); Tenente João Gualberto Stream, 26-II-2013, L.C. Servat (UNOP-Algae4057); Tenente João Gualberto Stream, 11-III-2013, L.C. Servat (UNOP-Algae4081); Tenente João Gualberto Stream, 4-IV-2013, L.C. Servat (UNOP-Algae4093); Tenente João Gualberto Stream, 9-V-2013, L.C. Servat (UNOP-Algae4102); Tenente João Gualberto Stream, 6-VI-2013, L.C. Servat (UNOP-Algae4116); Tenente João Gualberto Stream, 16-VII-2013, L.C. Servat (UNOP-Algae4126).

Occurrence in the Paraná State: First record of the taxon.

Euastrum croasdaleae Grönblad var. croasdaleae Acta Soc.Sci. Fennica Comm. Biol. 15(12): 25, fig. 30-32. 1956.

Figures 10-11

Cells longer than wide. L: 13.8-19.3 $\mu \mathrm{m}$; W: 9.2-13.2 $\mu \mathrm{m}$; I: 2.3-3.5 $\mu \mathrm{m}$. Deep median constriction, sinus narrow and closed, semicells pyramidal-truncate with lateral and apical margins retuse, a slight incision in the superior midregion. Face of the semicell with a slight protuberance and absence of granules. Lateral view oval. Apical view not observed. Cell wall smooth. Chloroplastid with one pyrenoid per semicell. 
Material examined: BRAZIL. PARANÁ: São Miguel do Iguaçu, Tenente João Gualberto Stream, 29-X-2012, L.C. Servat (UNOP-Algae3962); Tenente João Gualberto Stream, 11-III-2013, L.C. Servat (UNOPAlgae4081).

Occurrence in the Paraná State: First record of the taxon.

Euastrum denticulatum (Kirchner) Gay var. denticulatum, Bull. Soc. Bot. Fr. 31: 335. 1884.

Figures 12-13

Cells longer than wide. L: 13.3-24.6 $\mu \mathrm{m}$; $\mathrm{W}:$ 10.5-18.4 $\mu \mathrm{m}$; I: 2.9-5.7 $\mu \mathrm{m}$. Deep median constriction, sinus closed, semicell subtrapeziform, basal lobes rectangular, lateral margins undulated, notch between the basal and apical lobes open and shallow, apical lobe with deep median notch, short spine at each of the angles. Apical view elliptic with a protuberance. Lateral view not observed. Cell wall ornamented with granules. Chloroplastid with one pyrenoid per semicell.

Material examined: BRAZIL. PARANÁ: São Miguel do Iguaçu, Tenente João Gualberto Stream, 30-VIII-2012, L.C. Servat (UNOP-Algae3930); Tenente João Gualberto Stream, 25-IX-2012, L.C. Servat (UNOPAlgae3943); Tenente João Gualberto Stream, 6-VI-2013, L.C. Servat (UNOP-Algae4116).

Occurrence in the Paraná State: Felisberto \& Rodrigues (2005a, b, 2008, 2010), Bortolini et al. (2010), Aquino et al. (2014).

Euastrum denticulatum (Kirchn.) F. Gay var. quadrifarium Willi Krieg., in Kolkwitz, Rabenh. Krypt. -Fl., ed. 2. 13(1): 585, pl. 80, fig. 20-21. 1937.

Figure 14

Cells longer than wide. L: $20.6 \mu \mathrm{m}$; W: $16.8 \mu \mathrm{m}$; I: $5.1 \mu \mathrm{m}$. Deep median constriction, linear sinus closed, semicell subtretangular with subparallel lateral margins, apical margin truncate with a small incision $\mathrm{V}$-shaped. Face of the semicell with four large granules arranged in a circle, with two mucilage pores on either side and above the midregion. Apical and lateral view not observed. Cell wall punctate. Chloroplastid with one pyrenoid per semicell.

Material examined: BRAZIL. PARANÁ: São Miguel do Iguaçu, Tenente João Gualberto Stream, 29-X-2012, L.C. Servat (UNOP-Algae3962).
Occurrence in the Paraná State: First record of the taxon.

E. denticulatum var. quadrifarium differs from the typical variety by having its polar lobe more prominent, besides showing four granules arranged in circle, with two mucilage pores on either side and above the midregion (Prescott et al. 1977).

Euastrum didelta (Turpin) Ralfs var. quadriceps (Nordst.) Willi Krieg., in Kolkwitz, Rabenh. Krypt. -Fl., ed. 2. 13(1): 520, pl. 67, fig. 8-10. 1937.

Figures 15-17

Cells longer than wide. L: 93.6-96.8 $\mu \mathrm{m}$; $\mathrm{W}: 47.8-48.1 \mu \mathrm{m}$; I: 10.4-13.2 $\mu \mathrm{m}$. Deep median constriction, sinus narrow and closed, semicell pyramidal with rounded lateral margin and apical margin truncate, 3-lobed. Face of the semicell with two protrusions immediately below the polar lobe and with three tubercular swellings immediately above the isthmus. Apical and lateral view not observed. Cell wall grossly punctate. Central Chloroplastid. Pyrenoids not observed.

Material examined: BRAZIL. PARANÁ: São Miguel do Iguaçu, Tenente João Gualberto Stream, 30-VIII-2012, L.C. Servat (UNOP-Algae3930); Tenente João Gualberto Stream, 25-IX-2012, L.C. Servat (UNOPAlgae3943); Tenente João Gualberto Stream, 29-X-2012, L.C. Servat (UNOP-Algae3962).

Occurrence in the Paraná State: First record of the taxon.

E. didelta var. quadriceps differs from the typical variety by presenting three protrusions well-marked immediately below the isthmus and by showing cell wall grossly punctate (Silva \& Felisberto 2015). The individuals found showed inferior size than the ones cited by Prescott et al. (1977), which the length would be 114-132 $\mu \mathrm{m}$; width 51-66 $\mu \mathrm{m}$ and isthmus of 15-22 $\mu \mathrm{m}$, although all the other characteristics are in accordance with the description.

Euastrum elegans (Bréb.) Kütz. ex Ralfs var. elegans, Brit. Desmid.: 89, pl. 14, fig. 7a-c. 1848.

Figure 18-19

Cells longer than wide. L: 18.3-20.8 $\mu \mathrm{m}$; W: 12.8-15.5 $\mu \mathrm{m}$; I: 3.3-3.6 $\mu \mathrm{m}$. Deep median constriction, sinus narrow and closed. Semicell subretangular, lateral margins bilobed and retuse ending in a subapical spine, apical margin of the polar lobe elevated with a deep median incision, face of the 

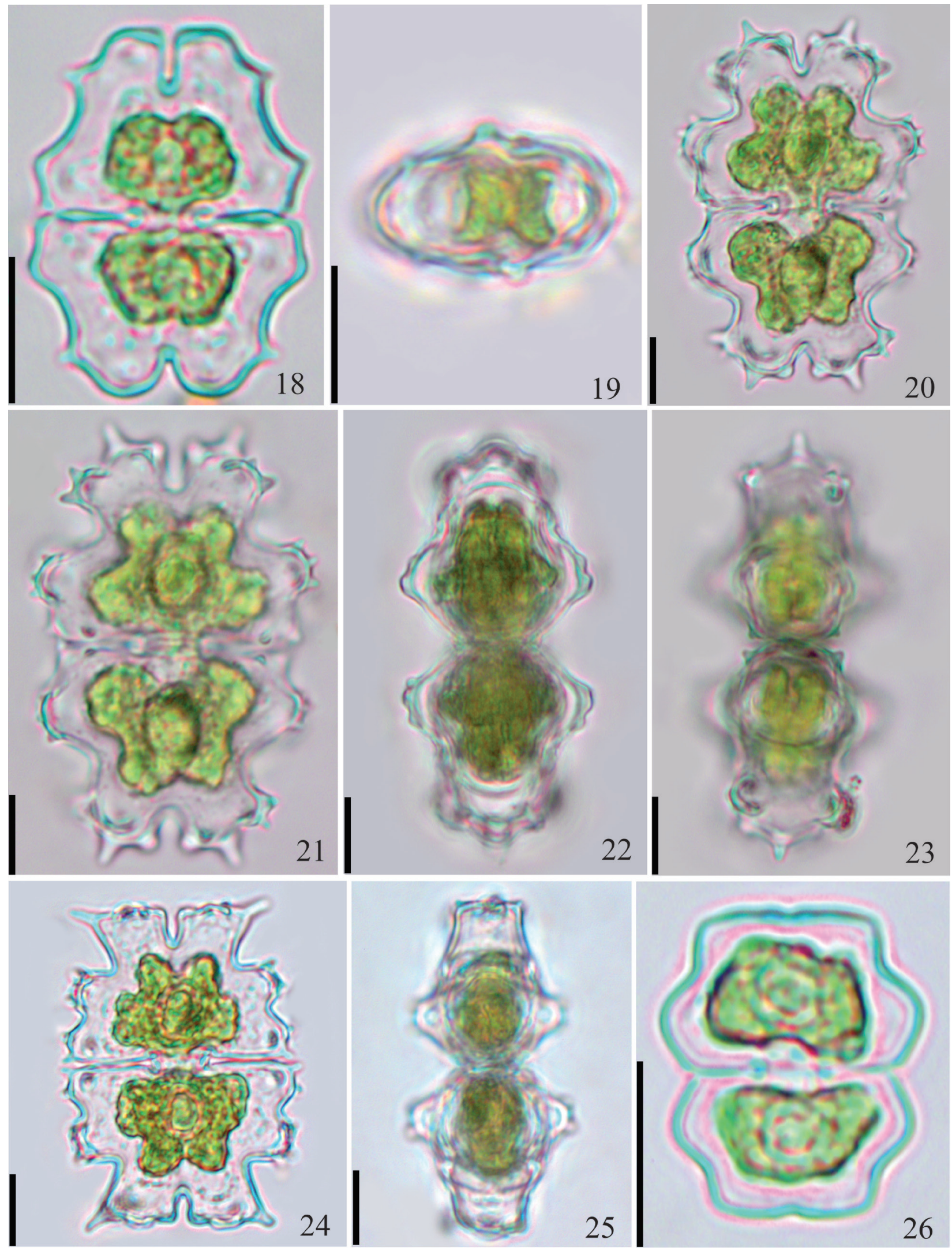

Figure 18-26. Euastrum Ehrenberg ex Ralfs in lotic environment adjacent to the Iguaçu National Park, Paraná, Brazil. 18-19. E. elegans var. elegans. 19. Apical view. 20-23. Euastrum evolutum var. evolutum. 21. Detail of the wall ornamentation. 22-23. Lateral view. 24-25. E. evolutum var. incudiforme. 25. Lateral view. 26. E. insulare. Scale $=10 \mu \mathrm{m}$. 
semicell with two tubercles in the midregion. Apical and lateral view not observed. Chloroplastid with one pyrenoid per semicell.

Material examined: BRAZIL. PARANÁ: São Miguel do Iguaçu, Tenente João Gualberto Stream, 30-VIII-2012, L.C Servat (UNOP-Algae3930); Tenente João Gualberto Stream, 25-IX-2012, L.C Servat (UNOPAlgae3943); Tenente João Gualberto Stream, 29-X-2012, L.C Servat (UNOP-Algae3962); Tenente João Gualberto Stream, 6-II-2013, L.C Servat (UNOPAlgae4057).

Occurrence in the Paraná State: First record of the taxon.

The individuals found presented inferior sized than the ones cited by Prescott et al. (1977), which the length would be 26.6-39 $\mu \mathrm{m}$; width 14-30 $\mu \mathrm{m}$ and isthmus of 4-8 $\mu \mathrm{m}$, although all the other characteristics are in accordance with the description.

Euastrum evolutum (Nordst.) West \& G.S. West var. evolutum, Trans. Linn. Soc. London, Bot. 2 5(5): 243, pl. 14, fig. 22. 1896.

Figures 20-23

Cells longer than wide. L: 42.8-55.6 $\mu \mathrm{m}$; W: 30-40.4 $\mu \mathrm{m}$; I: 8-8.9 $\mu \mathrm{m}$. Deep median constriction, median sinus linear, closed, cells subretangular in outline, semicell approximately trapeziform, with one median protrusion ornamented with 3 granules disposed in circle, apex truncate, median apical incision V-shaped or U-shaped. Lateral view oval, with narrow and acute spines. Apical view not observed. Chloroplastid with one pyrenoid per semicell.

Material examined: BRAZIL. Paraná: São Miguel do Iguaçu, Tenente João Gualberto Stream, 30-VIII-2012, L.C. Servat (UNOP-Algae3930); Tenente João Gualberto Stream, 25-IX-2012, L.C. Servat (UNOPAlgae3943); Tenente João Gualberto Stream, 29-X-2012, L.C. Servat (UNOP-Algae3962); Tenente João Gualberto Stream, 6-II-2013, L.C. Servat (UNOP-Algae4057).

Occurrence in the Paraná State: Felisberto \& Rodrigues (2010), Aquino et al. (2014).

Euastrum evolutum var. incudiforme (Börge) West \& West, Limn. Soc. Jour. Bot. 33: 292. 1898.

Figures 24-25

Cells longer than wide. L: 30.7-39.3 $\mu \mathrm{m}$; W: 20.3-27.3 $\mu \mathrm{m}$; I: 4-6.2 $\mu \mathrm{m}$. Deep median constriction, sinus linear closed. Semicells semicircular-trapezoidal with rounded angles, lateral margins deeply retuse to a superior lateral lobe with three prominent spines, deep sinus anvil-shaped between the lateral and polar lobe, apical margin truncate with a deep median incision extended by a prominent spine. Face of the semicell with an ornamented inflation bearing three granules. Lateral view oval. Cell wall with one intramarginal granule on either side of the median constriction. Chloroplastid with one pyrenoid per semicell.

Material examined: BRAZIL. PARANÁ: São Miguel do Iguaçu, Tenente João Gualberto Stream, 25-IX-2012, L.C. Servat (UNOP-Algae3943); Tenente João Gualberto Stream, 13-XI-2012, L.C. Servat (UNOPAlgae3976).

Occurrence in the Paraná State: First record of the taxon.

According to Prescot et al. (1977) E. evolutum var. incudiforme (Börges) West \& West differs from the typical variety by presenting smaller measures, two minute teeth on either side of the median incision and by not having intramarginal granules in the polar lobes. The individuals found presented inferior size than the ones cited by Prescott et al. (1977), which the length would be 50-60 $\mu \mathrm{m}$; width $36-39 \mu \mathrm{m}$ and isthmus of 7.5-10 $\mu \mathrm{m}$, although all the other characteristics are in accordance with the description.

Euastrum insulare (Wittrock) Roy var. insulare, Monogr. Scott. Nat. p. 68, fig. 4A. 1883.

Figures 26

Cells longer than wide. L: 10.4-16.4 $\mu \mathrm{m}$; W: 7.6-14.2 $\mu \mathrm{m}$; I: 2-3.7 $\mu \mathrm{m}$. Deep median constriction, sinus closed, semicell trapeziform, lateral margins slightly undulate, apical median incision deep. Lateral view oval. Apical view not observed. Cell wall smooth. Chloroplastid with one pyrenoid per semicell.

Material examined: BRAZIL. PARANÁ: São Miguel do Iguaçu, Tenente João Gualberto Stream, 30-VIII-2012, L.C. Servat (UNOP-Algae3930); Tenente João Gualberto Stream, 25-IX-2012, L.C. Servat (UNOPAlgae3943); Tenente João Gualberto Stream, 29-X-2012, L.C. Servat (UNOP-Algae3962); Tenente João Gualberto Stream, 18-XII-2012, L.C. Servat (UNOP-Algae4035); Tenente João Gualberto Stream, 11-III-2013, L.C. Servat (UNOP-Algae4081); Tenente João Gualberto Stream, 9-V-2013, L.C. Servat (UNOP-Algae4102); Tenente João Gualberto Stream, 6-VI-2013, L.C. Servat (UNOP-Algae4116); Tenente 
João Gualberto Stream, 16-VII-2013, L.C. Servat (UNOP-Algae4126).

Occurrence in the Paraná State: Felisberto \& Rodrigues (2005a, 2008), Bortolini et al. (2010), Menezes et al. (2011).

\section{Acknowledgments}

The authors would like to thank the Fundação Araucária for providing the post-graduate scholarship to CANA and LCS, also Conselho Nacional de Desenvolvimento Científico e Tecnológico - CNPq for providing the post-doctoral scholarship to JCB (process 165796/2015-4). NCB is grateful to the Conselho Nacional de Desenvolvimento Científico e Tecnológico - CNPq, for the research grant (process 307196/2013-5).

\section{Literature cited}

Alvares, C.A., Stape, J.L., Sentelhas, P.C., Gonçalves, J.L.M. \& Sparovek, G. 2014. Köppen's climate classification map for Brazil. Meteorologische Zeitschrift 22: 711-728.

Aquino, C.A.N., Bueno, N.C. \& Menezes, V.C. 2014. Desmidioflórula (Zygnemaphyceae, Desmidiales) do rio Cascavel, Oeste do Estado do Paraná, Brasil. Hoehnea 41: 365-392.

Bicudo, C.E.M. \& Menezes, M. 2006. Gêneros de algas de águas continentais do Brasil: chave para identificação e descrições. 2 ed. RiMa, São Carlos.

Biolo, S., Siqueira, N.S. \& Bueno, N.C. 2008. Desmidiaceae (exceto Cosmarium) de um tributário do Reservatório de Itaipu, Paraná, Brasil. Hoehnea 35: 145-162.

Bortolini, J.C., Meurer, T. \& Bueno, N.C. 2010a. Desmidias (Zygnemaphyceae) do Rio São João, Parque Nacional do Iguaçu, Paraná, Brasil. Hoehnea 37: 293-313.

Bortolini, J.C., Moresco, C., Siqueira, N.S., Biolo, S., Meurer, T. \& Bueno, N.C. 2008. Desmidiaceae do Lago Municipal de Cascavel, Paraná, Brasil. Revista Brasileira de Biociências 6: 19-21.
Felisberto, S.A. \& Rodrigues, L. 2005a. Influência do gradiente longitudinal (rio-barragem) na similaridade das comunidades de desmídias perifíticas. Revista Brasileira de Botânica 28: 241-254.

Felisberto, S.A. \& Rodrigues, L. 2005b. Abundance of periphytic desmids in two Brazilian reservoirs with distinct environmental conditions. Acta Limnologica Brasiliensia 17: 433-443.

Felisberto, A.S. \& Rodrigues, L. 2008. Desmidiaceae, Gonatozygaceae e Mesotaeniaceae na comunidade perifítica do reservatório de Salto do Vau (Bacia do rio Iguaçu, PR). Hoehnea 35: 235-254.

Felisberto, S.A. \& Rodrigues, L. 2010. Periphytic algal community in artificial and natural substratum in a tributary of the Rosana reservoir (Corvo Stream, Paraná State, Brazil). Acta Scientiarum Biological Sciences 34: 365-371.

Franceschini, I.M., Burlinga, A.L., Reviers, B., Prado, J.F. \& Rèzig, S.H. 2010. Algas. 1 ed. Artmed, Porto Alegre.

Guiry, M.D. \& Guiry, G.M. 2016. AlgaeBase. World-wide electronic publication, National University of Ireland, Galway. Available in http://www.algaebase.org (access in 17-V-2016).

Menezes, V.C., Bueno, N.C. \& Bortolini, J.C. 2011. Composição florística de Desmidiales (exceto Cosmarium) em um lago subtropical brasileiro. Revista Brasileira de Biociências 9: 465-476.

Menezes, V.C., Bueno, N.C., Sobjak, T.M., Bortolini, J.C. \& Temponi, L.G. 2013. Zygnemaphyceae associada à Utricularia foliosa L. no Parque Nacional do Iguaçu, Paraná, Brasil. Iheringia Série Botânica 68: 5-26.

NCBI. 2016. National Center for Biotechnology Information. Bethesda, U.S.A. Available in https:// blast.ncbi.nlm.nih.gov (access 20-III-2016).

Picelli-Vicentim, M.M., Treuersch, M. \& Domingues, L.L. 2001. Fitoplâncton da Represa do Passaúna, Estado do Paraná, Brasil. Hoehnea 28: 53-76.

Prescott, G.W., Croasdale, H.T., Vinyard, W.C. \& Bicudo, C.E.M. 1977. A Synopsis of North American Desmids: part II. Desmidiaceae: Placodermae. Section 2-3. Lincoln: University of Nebraska Press.

Silva, F.K.L.S. \& Felisberto, A.S. 2015. Euastrum and Micrasterias (family Desmidiaceae) in lentic tropical ecosystem, Brazil. Biota Neotropica 15: 1-13. 